\title{
CHLOROTIC SPOTS ON Clerodendrum, A DISEASE CAUSED BY A NUCLEAR TYPE OF Brevipalpus (ACARI: TENUIPALPIDAE) TRANSMITTED VIRUS
}

\author{
Elliot Watanabe Kitajima ${ }^{1 *}$; Karen Sumire Kubo²; Paulo de Tarso Oliveira Ferreira²; Berenice \\ Kussumoto de Alcântara ${ }^{3}$; Alessandra Jesus Boari; Renata Takassugi Gomes²; Juliana Freitas- \\ Astua $^{5,6}$; Jorge Alberto Marques Rezende ${ }^{1}$; Gilberto José de Morais ${ }^{1}$; Renato Barbosa Salaroli ${ }^{1}$ \\ ${ }^{1}$ USP/ESALQ - Depto. de Entomologia, Fitopatologia e Zoologia Agrícola, C.P. 09 - 13418-900 - Piracicaba, SP - \\ Brasil. \\ ${ }^{2} U S P / E S A L Q$ - Programa de Pós- Graduação em Fitopatologia. \\ ${ }^{3}$ USP/ESALQ - Graduanda em Engenharia Florestal. \\ ${ }^{4}$ Universidade Federal de Sergipe - Depto. de Agronomia, Av. Marechal Rondon, s/n - 49100-000 - São Cristóvão, \\ SE - Brasil. \\ ${ }^{5}$ Embrapa Mandioca e Fruticultura Tropical - Rua Embrapa, s/n - 44380-000 - Cruz das Almas, BA - Brasil. \\ ${ }^{6}$ IAC/APTA - Centro Citros "Sylvio Moreira”, C.P. 4 - 13490-970 - Cordeirópolis, SP - Brasil. \\ *Corresponding author <ewkitaji@esalq.usp.br>
}

ABSTRACT: Chlorotic spots have been observed in plants of Clerodendrum $x$ speciosum growing in residential gardens and parks in Piracicaba, SP, Brazil. Thin sections of diseased tissues revealed characteristic cytopathic effects of the nuclear type of the Brevipalpus (Acari: Tenuipalpidae) mitetransmitted viruses (BTrV). Brevipalpus mites, identified as B. phoenicis, infesting symptomatic C. $x$ speciosum plants transmitted the pathogen to healthy C. $x$ speciosum and to C. thomsonae, Gomphrena globosa, Hibiscus cannabinus, H. coccineus, H. schizopetalus, Salvia leucantha, Spathiphyllum wallasi and Tetragonia expansa causing chlorotic spots on their leaves. Mechanical inoculation using leaf extracts from infected C. x speciosum resulted in chlorotic spots on inoculated C. $x$ speciosum, Chenopodium quinoa, C. amaranticolor, G. globosa, H. cannabinus, H. coccineus and T. expansa leaves. C. amaranticolor and C. quinoa kept at $28-30^{\circ} \mathrm{C}$ became systemically infected. The same cytopathic effects caused by the nuclear type of BTrV were seen in tissues from all infected test plants by electron microscopy. The virus was purified from systemically infected leaves of $C$. amaranticolor and C. quinoa. A polyclonal antiserum obtained from an immunized rabbit presented a strong reaction with the homologous antigen in ELISA tests. The results suggest that this chlorotic spot disease of C. $x$ speciosum is caused by a new species of the nuclear type of BTrV, tentatively named Clerodendrum chlorotic spot virus (ClCSV).

Key words: Brevipalpus phoenicis, Clerodendrum x speciosum, host range, transmission, purification

\section{MANCHA CLORÓTICA DO Clerodendrum, UMA ENFERMIDADE CAUSADA POR UM VÍRUS DO TIPO NUCLEAR, TRANSMITIDO PELO ÁCARO Brevipalpus phoenicis (ACARI: TENUIPALPIDAE)}

RESUMO: Manchas cloróticas e necróticas foram observadas em folhas de várias plantas de coraçãosangrento (Clerodendrum x speciosum) cultivadas em parques e jardins em Piracicaba, SP, associadas à infestação pelo ácaro tenuipalpídeo Brevipalpus phoenicis. Exames preliminares de secções de tecido das manchas cloróticas ao microscópio eletrônico revelaram a ocorrência de efeitos citopáticos característicos dos induzidos pelos vírus do tipo nuclear, transmitido por ácaros Brevipalpus (VTB). Brevipalpus phoenicis coletados de C. $x$ speciosum sintomático e transferidos para plantas sadias de C. $x$ speciosum reproduziram as lesões. O ácaro também transmitiu o patógeno para C. thomsonae, Gomphrena globosa, Hibiscus cannabinus, H. coccineus, H. schizopetalus, Salvia leucantha, Spathiphyllum wallasi e Tetragonia expansa, as quais exibiram manchas cloróticas e/ou necróticas. O vírus também foi transmitido mecanicamente para Chenopodium amaranticolor, C. quinoa, G. globosa, $H$. cannabinus, $H$. coccineus e T. expansa, além de C. x speciosum. Plantas de $C$. amaranticolor e C. quinoa mantidas a $28-30^{\circ} \mathrm{C}$ desenvolveram infecção sistêmica. Em todos os tecidos sintomáticos das plantas-teste inoculadas, examinados ao microscópio eletrônico, foram encontrados efeitos citopáticos do tipo nuclear causado por VTB. O vírus foi purificado a partir de 
folhas com infecção sistêmica de C. amaranticolor e C. quinoa. Injeções de preparações purificadas em coelho geraram um anti-soro policlonal que reagiu especificamente com o antígeno homólogo em teste de ELISA. As evidências obtidas indicam que as manchas cloróticas do Clerodendrum estão associadas a um VTB do tipo nuclear, tentativamente denominado de vírus da mancha clorótica do Clerodendrum (Clerodendrum chlorotic spot virus- ClCSV).

Palavras-chave: Breviplapus phoenicis, Clerodendrum x speciosum, transmissão, gama de hospedeiras, purificação

\section{INTRODUCTION}

The genus Clerodendrum comprises about 400 species, most of which grow in warm temperate or tropical climates. The name is derived from the Greek words "Clerodendrum" for chance (klero) and tree (dendrum) and refers back to the original species name "fortunate". Many publications refer to this genus as Clerodendron but Clerodendrum is the official spelling. Originally considered as a member of the family Verbenaceae, the genus Clerodendrum is now considered as a member of the family Lamiaceae based on cladistic analysis of the chloroplast DNA and internal transcriber spacer sequences (Steane et al., 2004). Clerodendrum plants appear as trees, shrubs and scrabbles and are commonly used as ornamentals (KVL, 2006). Clerodendrum thomsonae Baulf. (bleeding heart), C. x speciosum Tiej. et Bin. (glorybower, Java glory vine, heart vine, Pagoda flower) and C. splendens G. Don. (flaming glorybower) are among the most cultivated in home gardens and parks in Brazil and elsewhere, covering fences and walls (Lorenzi \& Souza, 2001) (Figure $1, \mathrm{~A}-\mathrm{C})$. There are few reports of viral diseases affecting plants of this genus. A yellow mosaic of $C$. inerme, caused by a begomovirus was reported in India (John et al., 2006) and a vein clearing of C. $x$ speciosum, associated with an unidentified rhabdovirus, was found in Brazil (Schuta et al., 1997).

Plants of C. $x$ speciosum exhibiting chlorotic and necrotic spots on their leaves (Figure 1, G) were found in a residential garden at Piracicaba, SP, Brazil, infested by mites identified as Brevipalpus phoenicis (Geijskes) (Figure $1 \mathrm{D}, \mathrm{F}$ ). Electron microscopic examination of the tissue sections of these spots revealed cytopathic effects of the nuclear type of the Brevipalpus mite transmitted viruses (BTrV) (Kitajima et al., 2003). Similar symptoms, always associated with Brevipalpus mite infestation, were also found in $C$. thomsonae and $C$. splendens (Figure $1 \mathrm{H}, \mathrm{I}$ ) in Piracicaba and other cities of the states of São Paulo, Santa Catarina, Amazonas and Distrito Federal. In C. thomsonae, brownish spots were also observed on flower petals (Figure 1, J) when infested by Brevipalpus (Figure 1, E).

Brevipalpus (Acari: Tenuipalpidae) mites transmit an ever increasing list of plant viruses among them some of economical importance such as Citrus leprosiscytoplasmic type (CiLV-C), Orchid fleck (OFV), Cof- fee ringspot (CoRSV) and Passion fruit green spot (PFGSV) (Kitajima et al., 2003; 2006b). The Brevipalpus genus includes about 300 species worldwide (Welbourn et al., 2003), but only three species (B. californicus (Banks), B. obovatus Donnadieu and $B$. phoenicis) are involved in plant virus transmission so far (Childers et al., 2003a). These three species may naturally infest up to 900 different plant species in 513 genera and 139 families (Childers et al., 2003b). Despite the worldwide distribution in tropical and subtropical regions of these mites, infection of plant viruses transmitted by Brevipalpus (BTrV) are restricted to the American continent. Natural infection by BTrVs include more than 40 plant species of 24 botanical families (Kitajima et al., 2003; 2006b). The only exception is OFV which has been found worldwide in orchids (Kondo et al., 2003).

This study presents a detailed description of the transmission and host range of a new species of a nuclear type of BTrV isolated from the chlorotic spots on leaves of C. $x$ speciosum, which is tentatively named Clerodendrum chlorotic spot virus (ClCSV). Results of cytopathology, purification and serology are also reported.

\section{MATERIAL AND METHODS}

Virus source - Clerodendrum x speciosum plants growing in Piracicaba, State of São Paulo, Brazil (22 $43^{\prime} \mathrm{S}$ and $47^{\circ} 38^{\prime} \mathrm{W}$ ) exhibiting chlorotic spots on the leaves and heavily infested with $B$. phoenicis were used as source of inoculum of the virus. Infection was confirmed by the presence of the nuclear type of BTrV by electron microscopy.

Mite transmission assays - adult mites, identified as B. phoenicis were collected with a fine needle from symptomatic C. $x$ speciosum plants and transferred to 39 species of test-plants (Tables 1 and 2) grown in pots in a greenhouse. Three plants of each species were used in the transmission tests, placing ten adult mites on four leaves of each tested plant. C. $x$ speciosum plants not infested by mites were used as control. The mites were kept on the plants for five days. After eliminating the mites with chemical sprays, they were kept for symptom development and, subsequently, analyzed by electron microscopy. 

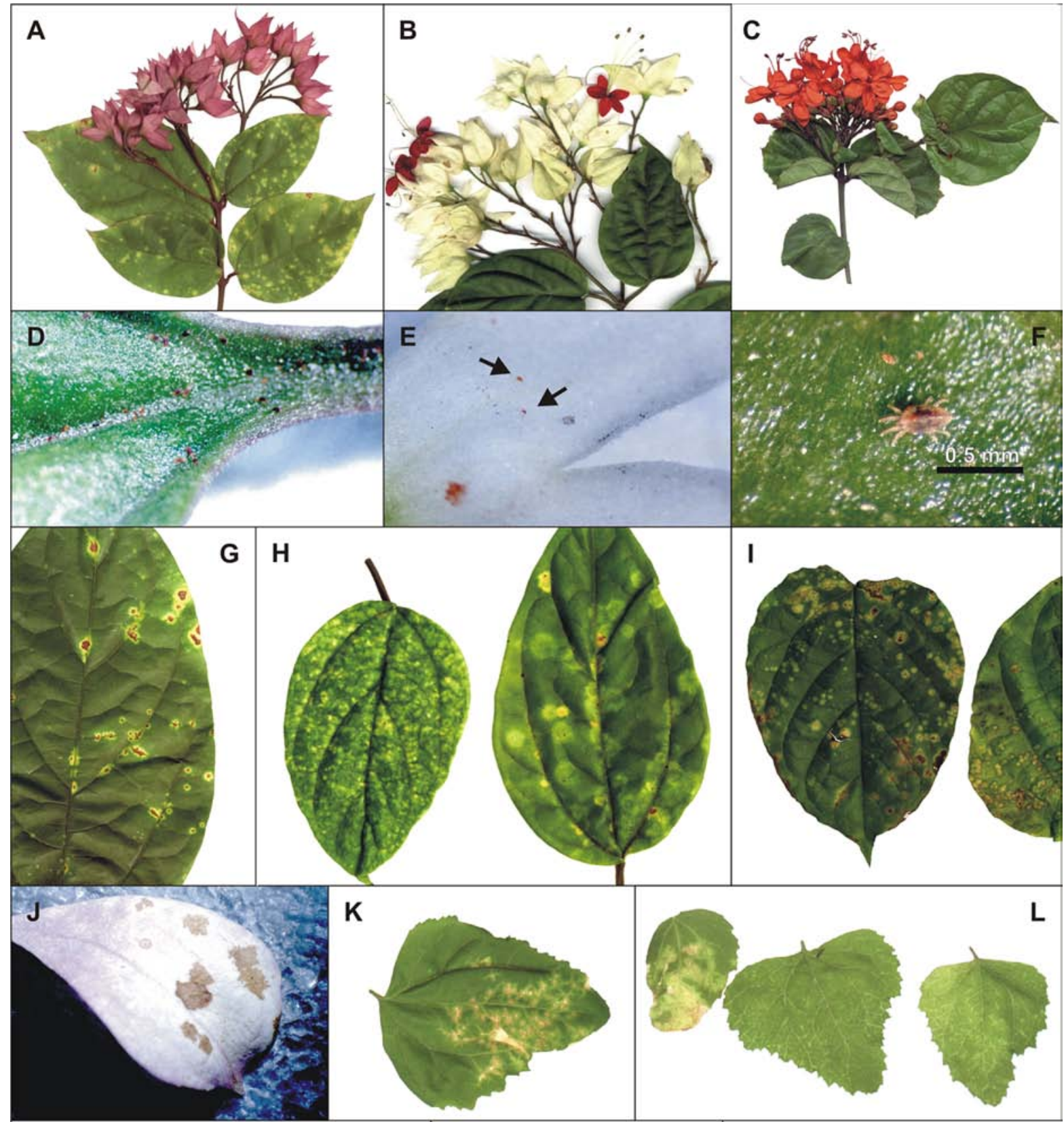

$\mathbf{L}$
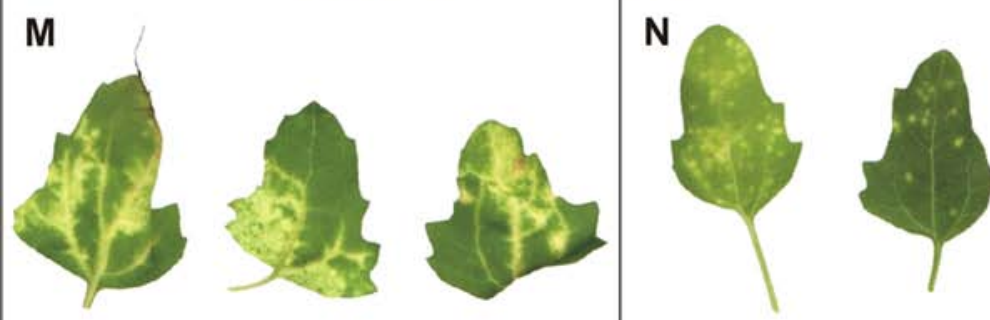

Figure 1 - A-C. Inflorescences of : A. Clerodendrum x speciosum. B. C. thomsonae. C. C. splendens. D. Part of a leaf of C. x speciosum heavily infested by B. phoenicis. E. The same mite infesting a petal of the flower of $C$. thomsonae. F. An adult female of $B$. phoenicis on the leaf of C. $x$ speciosum. G-I. Leaf symptoms caused by Clerodendrum chlorotic spot virus (ClCSV) in Clerodendrum species. G. Chlorotic spots with necrotic centers in C. x speciosum. H. Chlorotic spots in C. thomsonae. I. Chlorotic spots, some of them with necrotic center, in C. splendens. J. Brownish spots in the petal of $C$. thomsonae flower. K-N. Local lesions and systemic infection by ClCSV in mechanically inoculated Chenopodium quinoa and C. amaranticolor. Local lesions (K) and systemic symptoms (L) on the leaves of C. amaranticolor. Systemic infection (M) and local lesions (N) on the leaves of inoculated C. quinoa. 
Table 1 - List of plants tested for susceptibility to Clerodendrum chlorotic spot virus (ClCSV) by mite, mechanical and natural transmission and respective symptoms.

\begin{tabular}{lccc}
\hline Assayed plants & Mite $^{1}$ & Mechanical $^{2}$ & $\mathrm{Natural}^{3}$ \\
\hline Amaranthaceae & + & + & + \\
Gomphrena globosa L. & & + \\
Acanthaceae & &
\end{tabular}

Thunbergia erecta (Benth.) T. Anders.

$\mathrm{nt}^{5}$

$+^{6}$

Tetragonia expansa Murr.

Annonace ae

Annona muricata L.

\section{Apiaceae}

Hydrocotyle leucocephala (Cham \& Schltdl.)

Araceae
Diffenbachia sp.
Spathiphyllum wallisi Regel
Che nopodiaceae
Chenopodium quinoa Willd.
C. amaranticolor Coste \& Reyn.

\section{Commelinace ae}

Commelina sp.

\section{Geraniaceae}

Pelargonium hortorum L.

\section{Lamiace ae}

Clerodendrum x speciosum Tiejism. \& Binn.

Clerodendrum thomsonae Balfour

Clerodendrum splendens G. Don.

Salvia leucantha Cavanilles

\section{Malvaceae}

Hibiscus cannabinus L.

Hibiscus coccineus (Medik.) Walter

Hibiscus rosa-sinensis L.

Hibiscus schizopetalus Hook.f.

Hibiscus syriacus L.

Malvaviscus arboreus Cav.

\section{Orchidace ae}

Dendrobium sp.

Oncidium sp.

\section{Solanaceae}

Cestrum nocturnum L.

nt

$-\quad+4$

nt

nt

nt

-

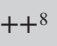

$++$

nt

$+$

$+\quad \mathrm{nf}^{\prime}$

$\mathrm{nf}^{7}$

$+$

nt

nt

$+$

$\begin{array}{lcc}+ & + & + \\ + & - & + \\ \text { nt } & \text { nt } & +9 \\ + & - & +\end{array}$

${ }^{1}$ Brevipalpus phoenicis. ${ }^{2}$ Extracts from local lesions of Chenopodium quinoa or C. amaranticolor used as inoculum. ${ }^{3}$ Plants growing next to a group of Clerodendrum x speciosum plants naturally infected by Clerodendrum chlorotic spot virus (ClCSV) and infested by B. phoenicis. $-^{4}$ no reaction. $\mathrm{nt}^{5}$ - not tested. $+{ }^{6}$ Local chlorotic lesions. Infection by ClCSV demonstrated by electron microscopic examination of the lesions and mechanical inoculation of C. quinoa and C.amaranticolor. $\mathrm{nf}^{7}$ - Plants not found near ClCSV - infected C.X splendens or $C$. thomsonae. $++^{8}$ Local chlorotic lesions followed by systemic infection (vein clearing and chlorotic spots) in uninoculated leaves when plants were kept at $28-30^{\circ} \mathrm{C}$ for 2 weeks. ${ }^{9}$ Natural infection in an isolated plant. 
Table 2 - Other plant species tested negative for mite, mechanical and natural transmission of the Clerodendrum chlorotic spot virus.

\begin{tabular}{|c|c|c|c|}
\hline & Mite* & Mechanical & Natural \\
\hline \multicolumn{4}{|l|}{ Amaranthaceae } \\
\hline Amaranthus sp. & -1 & - & - \\
\hline Celosia cristata L. & $\mathrm{nt}^{2}$ & - & - \\
\hline Pfaffia glomerata (Spreng.) Pedersen & $\mathrm{nt}$ & - & - \\
\hline \multicolumn{4}{|l|}{ Acanthaceae } \\
\hline Barleria cristata $\mathrm{L}$. & $\mathrm{nt}$ & $\mathrm{nt}$ & - \\
\hline \multicolumn{4}{|l|}{ Amaryllidaceae } \\
\hline Eucharis grandifolia Planch \& Linden & nt & $\mathrm{nt}$ & - \\
\hline \multicolumn{4}{|l|}{ Apocynaceae } \\
\hline Allamanda schottii Pohl & - & - & - \\
\hline Catharanthus roseus (L.) G. Don & - & - & - \\
\hline
\end{tabular}

\section{Araceae}

Anthurium sp.

Colocasia esculenta (L.) Schott

Philodendron bipinnatifidum Schott

Scindapsus pictus Hassk.

$\begin{array}{lcc}\mathrm{nt} & \mathrm{nt} & - \\ \mathrm{nt} & - & - \\ \mathrm{nt} & \mathrm{nt} & - \\ \mathrm{nt} & - & - \\ - & & - \\ \mathrm{nt} & - & -\end{array}$

Araliaceae

Hedera canariensis Willd.

Schefflera actinophyla Harms.

Schefflera arboricola (Hayata) Merr.

nt

As te raceae

Ageratum conyzoides L.

nt

Bidens pilosa L.

Dahlia pinnata Cav.

$-$

Emilia coccinea (Sims.) F.Don

Helianthus annuus L.

Tagetes minuta L.

nt

Zinnia elegans Jacq.

\section{Caricaceae}

Carica papaya L.

\section{Convulvulaceae}

Ipomoea carnea Jacq.

Dioscore ace ae

Dioscorea cayennensis Lam.

nt

\section{Euphorbiace ae}

Euphorbia heterophylla L.

Manihot esculenta Crantz

nt

nt

Lamiaceae

Salvia splendens Sellow ex. Roem \& Schult

Solenostemon sp. (=Coleus sp.) nt

nt

$\begin{array}{lc}- & \mathrm{nf}^{\beta} \\ - & - \\ - & - \\ - & - \\ - & - \\ - & \mathrm{nf}\end{array}$

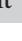

$-$

$-$

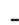

nt

$\begin{array}{lc}- & - \\ \text { nt } & - \\ \text { nt } & - \\ \text { nt } & - \\ - & -\end{array}$

Continue... 
Table 2 - Continuation.

\section{Leguminosae}

Cajanus cajan (L.) Millsp.

nt

Canavalia ensiformes DC

Canavalia rosea (Sw.) DC

Crotalaria juncea L.

Crotalaria ochroleuca G. Don

Dolichos lablab L.

Glycine max Merrill

Mucuna aterrima (Piper \& Tracy) Merr.

Mucuna cinereum L.

Phaseolus vulgaris L.

Senna occidentalis (L.) Link.

Styzolobium deeringianum Bort.

Vigna unguiculata (L.) Walp.

\section{Liliaceae}

Allium sp.

Cordyline terminalis (L.) Kunth

Dracaena sanderiana Hort.

\section{Malvaceae}

Abelmoschus esculenta (L.) Moench

Abutylon striatum Dicks. ex-Lindl.

Myrtaceae

Eugenia uniflora L.

Myrciaria cauliflora (DC.) Berg.

$\begin{array}{ll}\mathrm{nt} & \mathrm{nt} \\ \mathrm{nt} & \mathrm{nt}\end{array}$

Nyctaginaceae

Bougainvillea sp.
Mirabilis jalapa L.

$-$

Oleraceae

Ligustrum lucidum WT Aiton

Ligustrum sinense Lour.

Passifloraceae

Passiflora edulis Sims. f. flavicarpa Deg.

\section{Piperaceae}

Piper nigrum L.

Pittos poraceae

Pittosporum tobira (Thunb.) Ait.

\section{Plumbaginaceae}

Plumbago auriculata Lam.

\section{Rubiaceae}

Coffea arabica $\mathrm{L}$.

Ixora coccinea $\mathrm{L}$.

Mussaenda erythrophylla Schum.\& Thonn. nt

\section{nt}

nt

nt

nt

nt

nt

nt

nt

nt

nt

nt

- $\mathrm{nf}$

nf

nf

nf

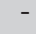

nf

nf
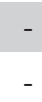

nf

nf nt

nt

$\mathrm{nt}$

nt nt

nt

nt

nt

nt

nt

nt

nt

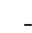

nt

nt

nt nt

nt 
Table 2 - Continuation.

\begin{tabular}{|c|c|c|c|}
\hline \multicolumn{4}{|l|}{ Rutaceae } \\
\hline Citrus sinensis (L.) Osbeck & - & - & - \\
\hline Murraya sp. & nt & nt & - \\
\hline \multicolumn{4}{|l|}{ Saxifragaceae } \\
\hline Hydrangea macrophylla (Thunb.) Serv. & $\mathrm{nt}$ & - & - \\
\hline \multicolumn{4}{|l|}{ Solanaceae } \\
\hline Brunfelsia uniflora (Pohl) D. Don & - & - & - \\
\hline Capsicum annuum L. & - & - & - \\
\hline $\begin{array}{l}\text { Datura suaveolens (Humb.\&Bonpl.) } \\
\text { Bercht.\&Presl. }\end{array}$ & - & - & - \\
\hline Datura stramonium L. & - & - & - \\
\hline Lycopersicon esculentum Mill. & - & - & - \\
\hline Nicotiana benthamiana Domin. & nt & - & $\mathrm{nf}$ \\
\hline Nicotiana clevelandii Gray & $\mathrm{nt}$ & - & - \\
\hline Nicotiana glutinosa L. & nt & - & - \\
\hline Nicotiana tabacum L. & - & - & - \\
\hline Solanum gilo Raddi & $\mathrm{nt}$ & - & - \\
\hline Solanum melongena L. & - & - & - \\
\hline Solanum violaefolium Schott. & - & - & - \\
\hline \multicolumn{4}{|l|}{ Urticaceae } \\
\hline Pilea cadierei Gagnep. \& Guillaumin & nt & nt & - \\
\hline \multicolumn{4}{|l|}{ Verbenace ae } \\
\hline Duranta repens $\mathrm{L}$. & $\mathrm{nt}$ & nt & - \\
\hline
\end{tabular}

*Brevipalpus phoenicis. ${ }^{1}{ }^{-}$No transmission. $\mathrm{nt}^{2}$ - Not tested. $\mathrm{nf}^{3}$ - Not found growing near Clerodendrum x speciosum

Mechanical transmission assays - Extracts from chlorotic spots on $C$. $x$ speciosum leaves were obtained by maceration in a $0.01 \mathrm{M}$ phosphate buffer, $\mathrm{pH} 7.0$ containing activated charcoal $(0.03 \% \mathrm{w} / \mathrm{v})$ and nicotine $(2 \% \mathrm{v} / \mathrm{v})$ (Chagas, 1978). In subsequent experiments, when transmission to Chenopodium quinoa Willd. and C. amaranticolor Coste \& Reyn. was achieved (initial chlorotic spots and systemically infected leaves when plants were maintained at $28-30^{\circ} \mathrm{C}$ for two weeks), these plants were used as source of inoculum. Extracts were obtained using $0.01 \mathrm{M}$ phosphate buffer, $\mathrm{pH} 7.0$, containing $0.1 \%$ sodium sulfite. Mechanical transmission tests were carried out with 65 different species of test-plants (Tables 1 and 2). Three to five test plants of each species were mechanically inoculated with the extract. Inoculation was made by rubbing the sap on the leaves dusted with carborundum.

Survey on possible natural infection by CICSV Other plant species (ornamentals, vegetables and fruit plants, weeds) are frequently present interspersed or next to symptomatic and Brevipalpus-infested C. $x$ speciosum plants. These plants were surveyed for symp- toms and the presence of the mites. Surveyed plants were located in the university campus of ESALQ and in three residential gardens of Piracicaba. A total of 87 species of plants growing under natural conditions (Tables 1 and 2) were surveyed for symptoms of chlorotic/necrotic lesions on the leaves. When leaves with suspected lesions were found, samples were collected and processed for electron microscopy analysis.

Electron microscopy - Small pieces of the chlorotic spots on the leaves (and in one case from a flower petal of C. thomsonae) were fixed in a modified Karnovsky solution (2\% paraformaldehyde, $2.5 \%$ glutaraldehyde in $0.05 \mathrm{M}$ cacodylate buffer, $\mathrm{pH}$ 7.2) for 1 - $2 \mathrm{~h}$, washed with buffer and post-fixed in $1 \%$ osmium tetroxide in the same buffer for $1 \mathrm{~h}$, dehydrated in a graded series of acetone, infiltrated and embedded in the low viscosity Spurr epoxy resin (Maunsbach \& Afezelius, 1999). Blocks were sectioned in a Leica UT ultramicrotome equipped with a diamond knife. The sections were collected on copper grids, stained with 3\% uranyl acetate and Reynold's lead citrate, and examined in a Zeiss EM 900 transmission electron microscope. 
Virus purification - Fresh leaves of C. amaranticolor and $C$. quinoa exhibiting symptoms of systemic infection were used for virus purification, based on the protocol used for CoRSV purification (Boari et al., 2004), which is the procedure used to purify OFV (Chang et al., 1976) with small modifications. Infected leaf tissues frozen in liquid nitrogen were ground in 0.1 $\mathrm{M}$ phosphate buffer, $\mathrm{pH} 7.0$, containing $0.01 \mathrm{M}$ sodium diethyl ditiocarbamide, $0.1 \%$ ascorbic acid and $5 \%$ Triton X-100. After clarification by low speed centrifugation, the suspension was centrifuged on top of a $20 \%$ sucrose cushion $(150 \mathrm{~min} / 40,000 \mathrm{~g})$. The pellet was resuspended in $0.1 \mathrm{M}$ phosphate buffer, $\mathrm{pH}$ 7.0, and submitted to a cycle of differential centrifugation and then centrifuged in a sucrose gradient $(10-40 \%)$ for $90 \mathrm{~min}$ at 40,000 $\mathrm{g}$. One $\mathrm{ml}$ fraction were collected and analyzed by spectrophotometry, and the fraction with the peak of nucleic acid absorbance was separated and centrifuged for 150 min at 40,000 $\mathrm{g}$. The pellet was resuspended and stored for antiserum production. A sample was examined in the electron microscope by negative staining with $1 \%$ uranyl acetate.

Antiserum production and ELISA - Four aliquots of $250 \mu \mathrm{L}$ of a purified preparation (ca. $20 \mu \mathrm{g} \mathrm{mL}^{-1}$ ), mixed with an equal volume of incomplete Freund's adjuvant, were injected intramuscularly in a rabbit at weekly intervals. One week after the last injection, the serum was collected and stored at $-20^{\circ} \mathrm{C}$ (Van Regenmortel, 1982). This antiserum was tested in Plate trapped antigen - Enzyme linked immunosorbent assay (PTA-ELISA) (Mowat \& Dawson, 1987) against purified virus and extracts from infected Clerodendrum. Antisera against OFV (Kondo et al., 1995) and CoRSV (Boari et al., 2004), and the respective antigens were also included in the test to analyze possible serological relationships. Appropriate healthy controls were included in homologous and heterologous reactions.

\section{RESULTS}

Symptoms - Symptoms caused by natural or experimental (mite or mechanical inoculation) transmission of ClCSV remained restricted to the inoculated leaves of susceptible hosts. The symptoms consisted usually of chlorotic spots (Figure $1 \mathrm{H}, \mathrm{I}, \mathrm{K}, \mathrm{N}$; Figure $2 \mathrm{~A}$, $\mathrm{B}, \mathrm{C}, \mathrm{F}, \mathrm{I}, \mathrm{J}, \mathrm{L}, \mathrm{N}, \mathrm{O}$ ), occasionally with a necrotic center (Figure 1 G, 2 E, H). Some hosts developed brownish (Figure $2 \mathrm{I}, \mathrm{K}$ ) or necrotic spots (Figure 2 $\mathrm{D}, \mathrm{M})$. In some few cases, the chlorotic spots became greenish when the leaves became senescent (Figure 2 A, C, G, H, I). Necrotic stem lesions were only no- ticed in $H$. cannabinus. In one instance, the white corolla of $C$. thomsonae growing in a residential garden presented brownish spots (Figure $1 \mathrm{~J}$ ).

Mite transmission tests - Mites (Figure 1 D, E, F) infesting C. $x$ speciosum, $C$. splendens and $C$. thomsonae exhibiting chlorotic lesions were identified as B. phoenicis based on external morphological characteristics (Welbourn et al., 2003). When mites collected from symptomatic C. $x$ speciosum plants were transferred to healthy ones, chlorotic spots became visible four to five weeks later. Electron microscopic examination confirmed the presence of cytopathic effects similar to those found in the source plant. After this initial experiment, similar mite transmission tests were performed on plants of 39 species (Tables 1 and 2). Chlorotic spots developed only in nine of the tested plant species (Clerodendrum thomsonae, C. $x$ speciosum, Gomphrena globosa, Hibiscus cannabinus, $H$. coccineus, H. schizopetalus, Salvia leucantha, Spathiphyllum wallisi and Tetragonia expansa). Electron microscopy confirmed the presence of cytopathic effects characteristic of the nuclear type of BTrV in these spots. Attempts to rear B. phoenicis collected from field Clerodendrum plants on C. $x$ speciosum or C. thomsonae under laboratory conditions were unsuccessful so far.

Mechanical transmission - Transmission of ClCSV was successfully achieved by mechanical means using C. $x$ speciosum as source of inoculum only when buffer containing nicotine and activated charcoal was used. In the initial trials, C. amaranticolor and $C$. quinoa demonstrated to be good indicator plants among those tested. Once infected, these plants became good sources of inoculum for mechanical transmission using routine phosphate buffer containing sodium sulfite. As already demonstrated with OFV and CoRSV, both C. quinoa and C. amaranticolor became systemically infected when kept at $28-30^{\circ} \mathrm{C}$ for $10-14$ days after inoculation. Systemically infected leaves of $C$. amaranticolor and/or C. quinoa were used as source of inoculum in later experiments. A total of 65 different plant species (Tables 1 and 2) were tested for mechanical transmission of ClCSV, but only six were susceptible (C. amaranticolor, C. quinoa, G. globosa, $H$. cannabinus, $H$. coccineus and $T$. expansa) besides $C$. $x$ speciosum. Transmission was confirmed by backinoculation to C. amaranticolor and C. quinoa.

Survey of plants naturally infected by CICSV - Because Brevipalpus mites are polyphagous (Childers et al., 2003b) it was assumed that many plants growing near ClCSV-infected and B. phoenicis-infested C. $x$ speciosum plants might become naturally infected. A 


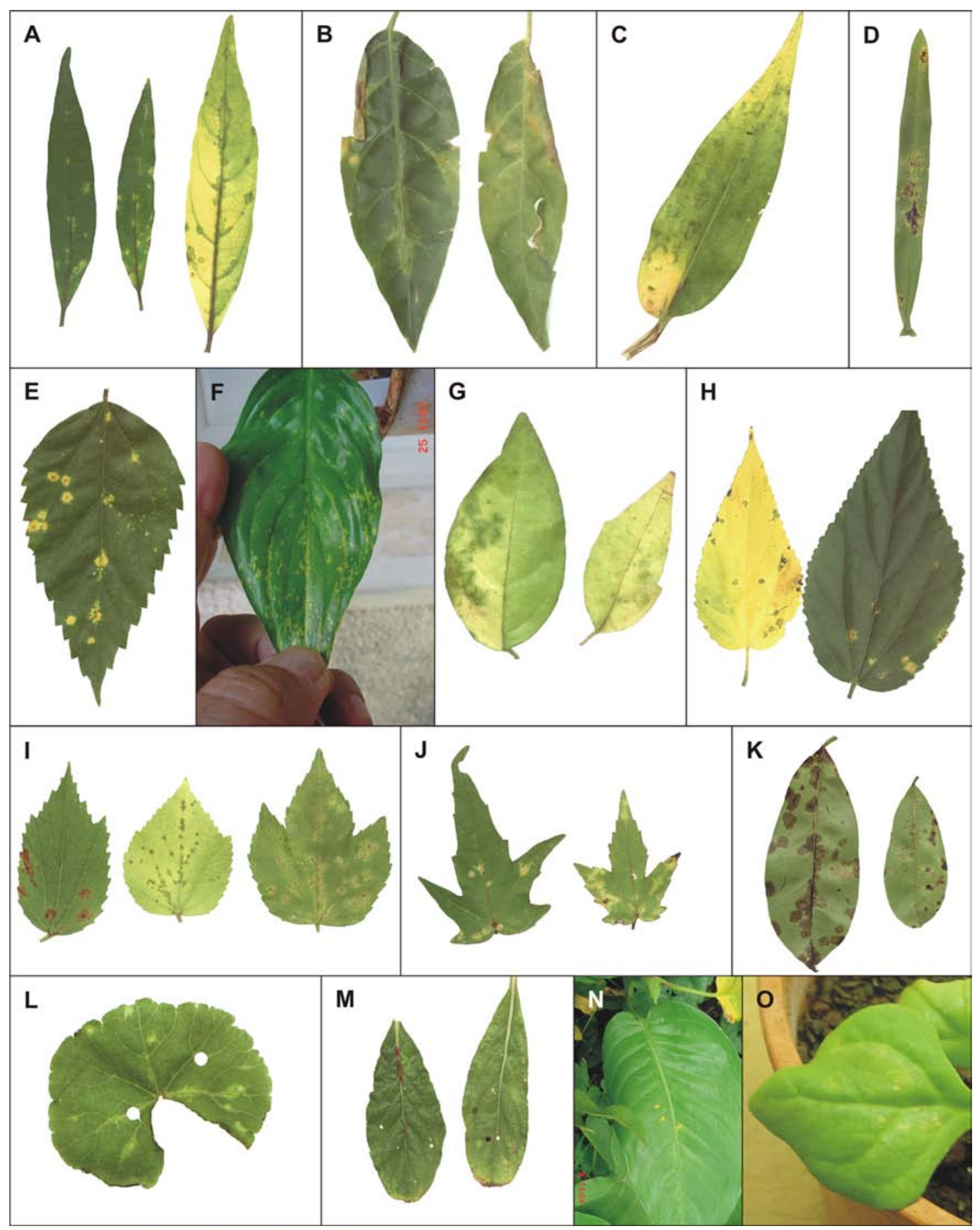

Figure 2 - A-O. Leaf symptoms on several plant species experimentally (mite or mechanical) or naturally infected by Clerodendrum chlorotic spot virus (ClCSV). A. Chlorotic spots on green leaves and green spots in senescent leaves of mite infected Salvia leucantha. B. Chlorotic spots or rings on the leaves naturally infected Cestrum nocturnum. C. Ringspot on a leaf of naturally infected Commelina sp. D. Necrotic ringspot on a leaf of naturally infected Oncidum sp. E. Chlorotic spots on a leaf of naturally infected Hibiscus schizopetalus. F. Chlorotic spots on a leaf of mite infected Spathiphyllum wallasi. G. Green spots on senescent leaves of naturally infected Thunbergia erecta. H. Chlorotic spots on a green leaf and green spots on senescent leaves of naturally infected Malvaviscus arboreus. I. Brownish and chlorotic spots on green leaves and green spots on a senescent leaf of Hibiscus cannabinus mechanically infected. J. Chlorotic spots on mite-inoculated leaves of Hibiscus coccineus. K. Large brownish spots on the leaves of naturally infected Annona muricata. L. Chlorotic spots on the leaf of naturally infected Hydrocotyle leucocephala. M. Necrotic spots on the leaves of mechanically inoculated Gomphrena globosa. N. Chlorotic spots on a leaf of naturally infected Diffenbachia sp. O. Chlorotic spots on a leaf of mechanically infected Tetragonia expansa. 
search, therefore, was carried out on such plants growing interspersed or next to ClCSV-infected C. $x$ speciosum for those showing localized symptoms on their leaves. A total of 87 different plant species were analyzed (Tables 1 and 2). In 19 of them (Annona muricata, Cestrum nocturnum, C. thomsonae, Commelina sp., Dendrobium sp., Difenbachia sp., G. globosa, $H$. cannabinus, $H$. coccineus, $H$. rosa-sinensis, H. schizopetalus, H. syriacus, Hydrocotyle leucocephala, Malvaviscus arboreus, Oncidium, Pelargonium hortorum, S. leucantha, S. wallisi and Thunbergia erecta) chlorotic or ringshaped spots were noticed. Few isolated $C$. splendens plants with chlorotic spots on their leaves were found in residential gardens. These spots were sampled and examined by electron microscopy. In all of them the characteristic cytopathic effects of the nuclear type of BTrV were observed.

Electron microscopy - Cell alterations characterized by an electron lucent inclusion (viroplasm) in the nucleus and the presence of short rod shaped particles (ca. $40 \mathrm{~nm} \times 100-110 \mathrm{~nm}$ ) in the nucleus or cytoplasm were observed in the tissues of all symptomatic plants, obtained by natural or experimental (mite or mechanical) transmission of the virus (Figure $3 \mathrm{~A}$ D). In the nucleus, these rodlike particles could appear scattered within viroplasm or nucleoplasm and sometimes arranged side-by-side forming lamellar aggregates (Figure $3 \mathrm{~B}$ ). Also, they commonly appear either in the nucleus or in the cytoplasm arranged perpendicularly onto membranous system of the nuclear envelope or endoplasmic reticulum (Figure $3 \mathrm{C}$ ). This arrangement is reminiscent of early phases of the budding process during morphogenesis of most of the membrane bound viruses, which ends up with the complete envelopment of the nucleocapsid by the membrane. However, with the nuclear type of BTrV (Kitajima et al., 2003) this budding process appears to be incomplete in most cases. In some instances the endoplasmic reticulum cisternae form a tubular array with the particles arranged in a radial configuration inside, producing a figure referred to as "spoke wheel" (Figure $3 \mathrm{C}, \mathrm{D}$ ). These cell changes are characteristic of the so-called nuclear type of BTrV, and served as evidence that these plants are infected by ClCSV.

Virus purification - The protocol used for purification of OFV and CoRSV was successfully used to purify ClCSV from extracts of systemically infected leaves of C. amaranticolor and C. quinoa. Examination of the fraction which had a UV absorption for nucleic acid contained a large amount of short bullet shaped particles $40 \mathrm{~nm}$ wide and 100 - $110 \mathrm{~nm}$ long, with cross striation of $5 \mathrm{~nm}$, essentially similar to those observed in purified preparations of OFV and CoRSV
(Figure 3 E). Mechanical inoculation of these preparations caused local lesions in C. quinoa. Transmission electron microscopy of these lesions indicated the presence of typical cytopathic effects caused by a nuclear type of $\mathrm{BTrV}$, thus confirming that the purified preparations were infectious.

PTA-ELISA - The purified preparations of ClCSV strongly reacted with the produced homologous antiserum in PTA-ELISA. Antisera against OFV and CoRSV only reacted weakly with purified ClCSV (data not shown), suggesting that it may differ from OFV and CoRSV, but may share some common antigens or epitopes.

\section{DISCUSSION}

The chlorotic spots occurring naturally in at least three Clerodendrum species (C. $x$ speciosum, $C$. thomsonae, $C$. splendens) are caused by a nuclear type of BTrV, which is named Clerodendrum chlorotic spot virus (ClCSV). The virus is naturally transmitted by mites and by mechanical inoculation to several other plant species. Nineteen of 87 plants growing near ClCSV-infected C. $x$ speciosum (Table 1 ) showed localized infection with cytopathic effects characteristic of the nuclear type of BTrV. They were possibly infected by B. phoenicis that acquired the ClCSV from infected $C$. $x$ speciosum plants. Few isolated $C$. splendens plants were also found to be infected by ClCSV. Experimental mite transmission tests resulted in the infection of some of these plants (G. globosa, $H$. cannabinus, $H$. coccineus, S. leucantha, S. wallasi). Infection of $H$. cannabinus, $H$. coccineus, $S$. leucantha and Dendrobium sp., could be demonstrated by mechanical inoculation on C. amaranticolor and $C$. quinoa. With 14 species of these plants, mechanical recovery of the virus was unsuccessful possibly due to inhibitors present in the extracts. Further studies are required to confirm infection of these plants by immunological or molecular tools to detect ClCSV.

Two orchid species (Dendrobium sp. and Oncidium sp.) growing amidst ClCSV infected C. $x$ speciosum presented leaf lesions undistinguishable from those caused by OFV. However, extracts from the lesions did not react with OFV antiserum, and no amplification was obtained by RT-PCR using primers specific for OFV (data not shown). It is likely that these orchid species were infected by an isolate of ClCSV but further tests are required to confirm this hypothesis.

As it happens with two other nuclear type $\mathrm{BTrV}$, respectively OFV (Kondo et al., 1995) and CoRSV (Boari et al., 2003), mechanical infection of 

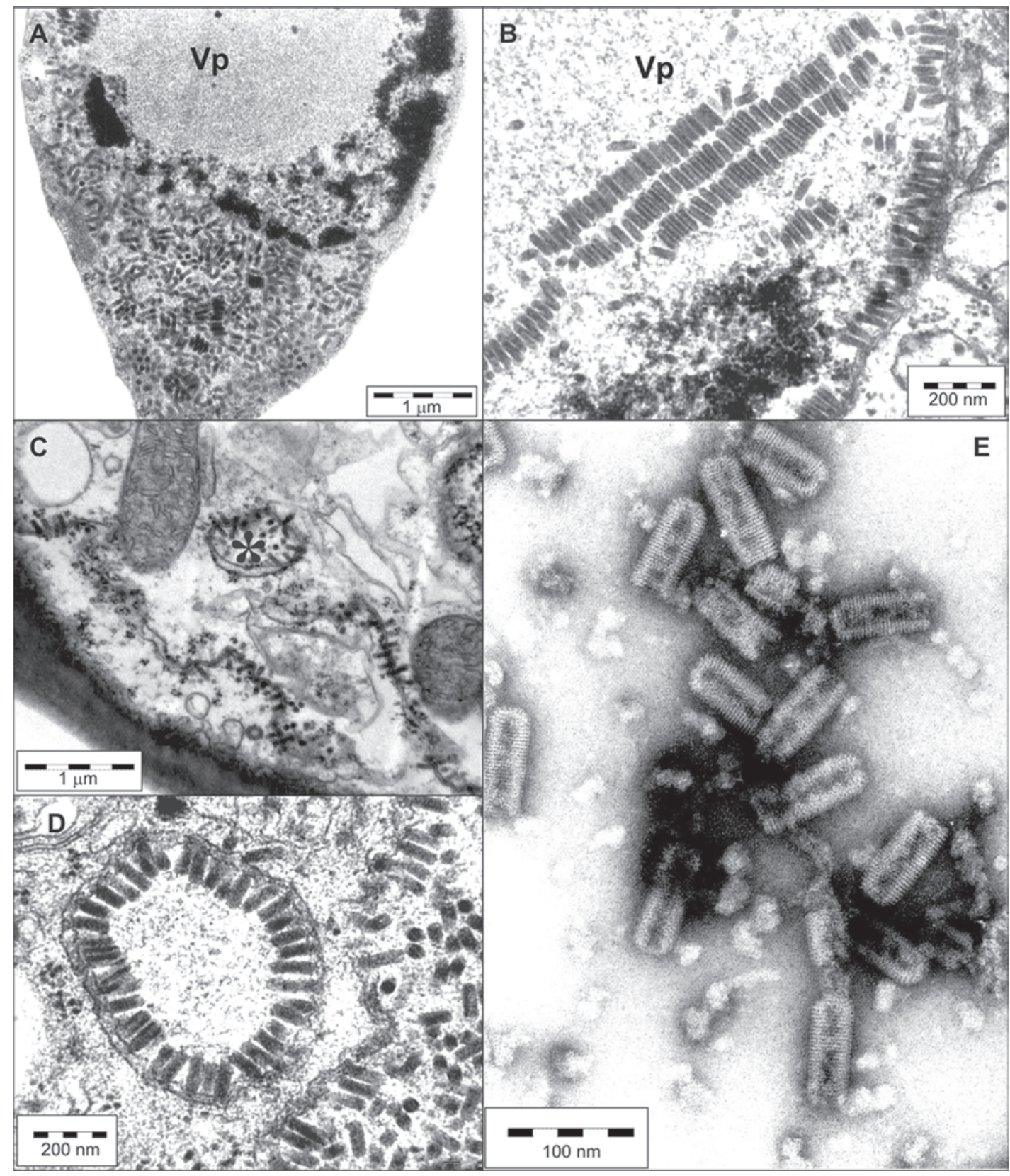

Figure 3 - A-D. Transmission electron micrographs of thin sections of Clerodendrum chlorotic spot virus (ClCSV)-infected leaf tissues: A. A nucleus in a leaf parenchyma cell of Clerodendrum x speciosum. A large viroplasm (Vp) and a mass of presusmed rodlike virions are visible. B. Large parallel aggregate of presumed rodlike particles near to the viroplasm (Vp). A group of particles can also be seen arranged perpendicularly onto the inside of the nuclear envelope in a leaf parenchyma cell of Chenopodium quinoa mechanically infected. C. Part of the cytoplasm of a leaf parenchyma cell in a chlorotic spot of Hibiscus cannabinus experimentally infected by Brevipalpus phoenicis. Rod-shaped, presumed virions, appear arranged perpendicularly onto the endoplasmic reticulum elements. A spoke wheel configuration is visible $(*)$. D. Detail of a spoke wheel configuration in a leaf parenchyma cell of a chlorotic spot of naturally infected Malvaviscus arboreus. E. Purified preparation of ClCSV obtained from systemically infected Chenopodium amaranticolor and C. quinoa negatively stained with uranyl acetate. A round end and cross striations are clearly visible on the rod shaped virions of ClCSV.

C. amaranticolor and C. quinoa with ClCSV resulted in local chlorotic spots and if the plants are maintained at high temperatures $\left(28-30^{\circ} \mathrm{C}\right)$, systemic infection occurs in the form of chlorotic spots or vein clearing. The systemic infection in hosts as $C$. amaranticolor and C. quinoa may be a common fea- ture for most of the nuclear type of BTrV and deserves attention to understand why temperature may affect the mechanisms that tend to restric the infection. In other susceptible plant species, however, systemic infection was not yet observed under similar conditions. 
Based on symptoms and electron microscopy examination of the infected tissues, the causal agent of some reported diseases like Malvaviscus ringspot (Kitajima et al., 2003), Soursop (Annona muricata) ringspot (Bitancourt, 1955; Kitajima et al., 2003) and Hibiscus chlorotic spot (Kitajima \& Rodrigues, 2001) may be caused by ClCSV. Similar symptoms were observed for these plants growing near to ClCSV-infected C. $x$ speciosum as above cited, and presumed to be naturally inoculated by the mite vector. This possibility will be evaluated using immunological and molecular techniques.

Many hosts, which appeared not to be infected by ClCSV in this study like Citrus sinensis (Rodrigues et al., 2003a), Pittosporum tobira (Rodrigues et al., 2003b), Piper nigrum (Yamashita et al., 2004), Allamanda schottii, Hedera canariensis, Bidens pilosa and Mussaenda erythrophylla (Rodrigues et al., 2005) were reported to be infected by the nuclear type of BTrV. Now that immunological and molecular tools are available for three of the nuclear types of BTrV, respectively ClCSV, CoRSV and OFV, it will be possible to assess whether or not other diseases for wich cytopathology indicates the presence of the nuclear type of BTrV represent infection by isolates of one of these viruses or a different virus.

So far, except for OFV, known BTrV are restricted to the American continent (Kitajima et al., 2003; 2006a) although Brevipalpus species that serve as vector are dispersed worldwide in tropical and subtropical regions (Childers et al., 2003b). The worldwide occurrence of OFV is explainable by the intense exchange of living plants which certainly resulted in the introduction of the virus and the vector, even in temperate regions. The absence of BTrVs in other parts of the world, however, is circumstantial and based on observations made only in parts of South Africa, Australia and few countries in Southeast Asia (J.C.V. Rodrigues and E.W. Kitajima, unpublished results) and a wider survey is required to confirm these observations. ClCSV has been found naturally infecting Clerodendrum species in the states of São Paulo, Santa Catarina, Amazonas and Distrito Federal indicating a wide dispersion in Brazil and is likely to be present in other parts of the American continent.

Examination of thin sections of the tissues from the lesions of experimental or naturally ClCSV-infected plants appeared similar to those reported for other nuclear types of BTrV as OFV and CoRSV (Kitajima et al., 2003; Kondo et al., 2003; Chagas et al., 2003). Typical electron lucent viroplasm in the nucleus and short rod shaped particles were seen mostly in mesophyl parenchyma cells, and rarely in vascular parenchyma. The rod-like particles were demonstrated to be the virions by immunogold labeling in OFV-infected cells (Kitajima et al., 2001) and by analogy, those present in ClCSV-infected cells may represent ClCSV particles, though experimental demonstration is still required. These particles were commonly naked, without surrounding membrane, and quite often were perpendicularly arranged to the nuclear envelope or endoplasmic reticulum membranes, as shown for other nuclear type of $\mathrm{BTrV}$, a process suggesting that the envelopment of the particles is not completed after an initial start. In very rare instances, membrane bounded particles could individually be seen within endoplasmic reticulum elements, possibly after a successful budding process. A possible explanation might be that glycoprotein of most nuclear types of BTrV have some defect by which the budding process can not be completed and results in the accumulation of naked nucleocapsids. Similar observations were described for Tomato spotted wilt virus (Resende et al., 1991).

The same pattern of cell alterations observed in plant tissues was observed also in gland cells of $B$. phoenicis collected from ClCSV-infected plants (Kitajima et al., 2006a). This fact strongly suggests that the virus multiplies in the mite, thus B. phoenicis/ClCSV relationship is of the circulative/propagative type. This is in agreement with the conclusions reached in the transmission of OFV by B. californicus (Kondo et al., 2003).

Because systemically infected tissues contain more virus than in local lesions, as noticed by electron microscopy, this tissue was used to purify ClCSV. This was achieved using the protocol developed for OFV (Chang et al., 1976; Boari et al., 2004), and the purified particles looked essentially similar to those of OFV and CoRSV. The antiserum raised in rabbit against purified ClCSV was specific. Comparative PTA-ELISA using antibodies against OFV, CoRSV and ClCSV, and the respective homologous antigens, revealed strong homologous and faint heterologous reactions (data not shown). These results indicate that they are different viruses, but share some common epitopes. This is considered supplementary evidence that though belonging to the same genus, these three viruses are of different species. OFV genome has been completely sequenced and revealed to be negative sense ssRNA. Its genome is divided in two pieces of about $6 \mathrm{~kb}$ with gene organization similar to that of Rhabdoviruses. A new genus Dichorhabdovirus has been proposed for OFV (Kondo et al., 2006), of which CoRSV and ClCSV will be possible members. As soon as more informa- 
tion about ClCSV genome emerges, a better understanding of the phylogenetic relationship among these viruses is expected. Also, the development of molecular and immunological tools to detect ClCSV will help to confirm the cases of its natural transmission as well as the establishment of its natural host range, which is much wider than that of CoRSV and OFV.

\section{ACKNOWLEDGMENTS}

To FAPESP (2000/11805-0) and CNPq (41.0192/03-1). The authors are grateful to Dr. Kanchi Gandi from the International Plant Name Index for updating information regarding genus Clerodendrum.

\section{REFERENCES}

BITANCOURT, A.A. Estudos sobre a leprose dos citros. IDistribuição geográfica e sintomatologia. II. Transmissão natural às folhas. III.Transmissão natural às frutas. IV. Experiências de tratamento. Arquivos do Instituto Biológico, v.22, p.161231, 1955.

BOARI, A.J.; FIGUEIRA, A.R.; NEDER, D.G.; INFIESTA, L.R.; NOGUEIRA, N.L.; ROSSI, M.L.; KITAJIMA, E.W. Efeito da temperatura na infecção sistêmica de Chenopodium quinoa pelo Coffee ringspot virus (CoRSV). Fitopatologia Brasileira, v.28, p.246-247, 2003. Suplemento.

BOARI, A.J.; FREITAS-ASTUA, J.; FERREIRA, P.T.O.; NEDER, D.G.; NOGUEIRA, N.L.; ROSSI, M.L.; KITAJIMA, E.W. Purification and serology of the coffee ringspot virus. Summa Phytopathologica, v.30, p.453-458, 2004.

CHAGAS, C.M. Mancha anular do cafeeiro. São Paulo: USP/IB, 1978. 92p. (Tese - Doutorado).

CHAGAS, C.M.; KITAJMA, E.W.; RODRIGUES, J.C.V. Coffee ringspot virus vectored by Brevipalpus phoenicis (Acari: Tenuipalpidae) in coffee. Experimental and Applied Acarology, v.30, p.203-213, 2003.

CHANG, M.U.; ARAI, K.; DOI, Y.; YORA, K. Morphology and intracellular appearance of orchid fleck virus. Annals of the Phytopathological Society of Japan, v.42, p.156-167, 1976.

CHILDERS, C.C.; FRENCH, J.V.; RODRIGUES, J.C.V. Brevipalpus californicus, B. obovatus, B. phoenicis, and B. lewisi (Acari: Tenuipalpidae): a review of their biology; feeding injury and economic importance. Experimental and Applied Acarology, v.30, p.5-28, 2003a.

CHILDERS, C.C.; RODRIGUES, J.C.V.; WELBOURN, W.C. Host plants of Brevipalpus californicus, B. obovatus, and B. phoenicis (Acari: Tenuipalpidae) and their potential involvement in the spread of viral diseases vectored by these mites. Experimental and Applied Acarology, v.30, p.29-105, 2003b.

JOHN, P.; SIVALINGAM, P.N.; KUMAR, N.; MISHRA, A.; AHYLAWAT, Y.S.; MALATHI, V.G. A new begomovirus associated with yellow mosaic disease of Clerodendron inerme. Plant Pathology, v.55, p.291, 2006.

KITAJIMA, E.W.; RODRIGUES, J.C.V. Mancha verde e mancha clorótica de Hibiscus são causadas por tipos diferentes de vírus transmitidos por Brevipalpus. Summa Phytopathologica, v.27, p.105, 2001.

KITAJIMA, E.W.; KONDO, H.; MACKENZIE, A.; REZENDE, J.A.M.; GIORIA, R.; GIBBS, A.; TAMADA, T. Comparative cytopathology and immunocytochemistry of Japanese, Australian and Brazilian isolates of Orchid fleck virus. Journal of General Plant Pathology, v.67, p.231-237, 2001.
KITAJIMA, E.W.; CHAGAS, C.M.; RODRIGUES, J.C.V. Brevipalpus-transmitted plant virus and virus-like diseases: cytopathology and some recent cases. Experimental and Applied Acarology, v.30, p.135-160, 2003.

KITAJIMA, E.W.; MORAES, G.J.; CALEGÁRIO, R.F.; SALAROLI, R.B. Dados preliminares sobre detecção electronomicroscópica de vírus transmitidos por Brevipalpus (Acari: Tenuipalpidae) nos tecidos do ácaro vetor. In: SIMPÓSIO BRASILEIRO DE ACAROLOGIA, 1., Viçosa, 2006. Resumos. Viçosa, 2006a. p.248.

KITAJIMA, E.W.; MORAES, G.J.; RODRIGUES, J.C.V.; FREITAS-ASTUA, J. Plantas infectadas naturalmente por vírus transmitidos por ácaros Brevipalpus (Acari: Tenuipalpidae). In: SIMPÓSIO BRASILEIRO DE ACAROLOGIA, 1., Viçosa, 2006. Resumos. Viçosa, 2006b. p.251.

KONDO, H.; MATSUMOTO, J.; MAEDA, T.; INOUYE, N. Host range and some properties of orchid fleck virus isolated from oriental Cymbidium in Japan. Bulletin Research Institute for Bioresource, Okayama University, v.3, p.151-161, 1995.

KONDO, H.; MAEDA, T.; TAMADA, T. Orchid fleck virus: Brevipalpus californicus mite transmission, biological properties and genome structure. Experimental and Applied Acarology, v.30, p.215-223, 2003.

KONDO, H.; MAEDA, T.; SHIRAKO, Y.; TAMADA, T. Orchid fleck virus is a rhabdovirus with an unusual bipartite genome. Journal of General Virology, v.87, p.2413-2421, 2006.

KVL. September: Clerodendron trichotomum. Available at: http:/ /en.sl.kvl.dk/Faciliter/Arboretet/MaanedensPlante/2006/ September.aspx. 2006: Accessed at: 05 feb. 2007.

LORENZI, H.; SOUZA, H.M. Plantas ornamentais do Brasil. Arbustivas, herbáceas e trepadeiras. 3.ed. Nova Odessa: Instituto Plantarum, 2001. 1088p.

MAUNSBACH, A.B.; AFZELIUS, B. Biomedical electron microscopy. Illustrated methods and interpretations. San Diego: Academic Press, 1999. 548p.

MOWAT, W.P.; DAWSON, S. Detection and identification of plant viruses by ELISA using crude sap extracts and unfractioned sera. Journal of Virological Methods, v.15, p.233-247, 1987.

RESENDE, R.O.; DE HAAN, P.; ÁVILA, A.C.; KITAJIMA, E.W.; KORMELINK, R.; GOLDBACH, R.; PETERS, D. Generation of envelope and defective interfering RNA mutants of tomato spotted wilt virus by mechanical passage. Journal of General Virology, v.73, p.2375-2383, 1991.

RODRIGUES, J.C.V.; KITAJIMA, E.W.; CHILDERS, C.C.; CHAGAS, C.M. Citrus leprosis virus vectored by Brevipalpus phoenicis (Acari: Tenuipalpidae) on citrus in Brazil. Experimental and Applied Acarology, v.30, p.161-179, 2003a.

RODRIGUES, J.C.V.; ACHOR, D.S.; CHILDERS, C.C.; KITAJIMA, E.W. Three new host plants of the Brevipalpus borne virus found in United States. In: INTERNATIONAL CONGRESS OF ACAROLOGY, 11., Brisbane, 2003. Program and abstract book. Brisbane, 2003b.

RODRIGUES, J.C.V.; ANTONY, L.M.M.A.; KITAJIMA, E.W. Levantamento de vírus transmitidos por Brevipalpus (Acari: Tenuipalpidae) na região de Manaus e Urucu, AM. Summa Phytopathologica, v.31, p.26, 2005. Suplemento.

SCHUTA, L.R.; LIMA, M.L.R.C.; COSTA LIMA NETO, V. Transmissão do vírus do clareamento das nervuras de Clerodendron speciosum (Verbenaceae). Summa Phytopathologica, v.23, p.54, 1997.

STEANE, D.A.; DE KOK, R.P.J.; OLMSTEAD, R.G. Phylogenetic relationships between Clerodendrum (Lamiaceae) and other Ajugoid genera inferred from nuclear and chloroplast DNA sequence data. Molecular Phylogenetics and Evolution, v.32, p.39-45, 2004. 
VAN REGENMORTEL, M.H. Serology and immunochemistry of plant viruses. London: Academic Press, 1982. 302p.

WELBOURN, W.C.; OCHOA, R.; KANE, E.C.; ERBE, E.F. Morphological observations on Brevipalpus phoenicis (Acari: Tenuipalpidae) including comparisons with $B$. californicus and B. obovatus. Experimental and Applied Acarology, v.30, p.107-133, 2003.
YAMASHITA, S.; KITAJIMA, E.W. Nuclear type of Brevipalpus mite-transmitted virus found in chlorotic lesions of black pepper from Pará state, Brazil. Summa Phytopathologica, v.30, p.68, 2004.

Received March 13, 2007

Accepted August 14, 2007 